\title{
Contributing Factors in Academic Ethics Practices among Lecturers of Islamic Higher Education
}

\author{
Sufriadi Muhammad Yusuf, Mohd Zailani Mohd Yusoff*, Mohd Dzahir Kasa, Yahya Don, \\ Wan Husna Wan Mohd Zain
}

School of Education and Modern Languages, Universiti Utara Malaysia, Malaysia

Received March 6, 2020; Revised April 1, 2020; Accepted April 19, 2020

Copyright $\odot 2020$ by authors, all rights reserved. Authors agree that this article remains permanently open access under the terms of the Creative Commons Attribution License 4.0 International License

\begin{abstract}
The phenomenon of deterioration in academic ethics among lecturers is alarming in Indonesia. This is reflected in the decline in the value of integrity and the value of professionalism among lecturers. Therefore, this study focused on the contributing factors in academic ethics practices among lecturers of Islamic Higher Education in Aceh, Indonesia. This quantitative study method used descriptive survey whereby the data were collected using questionnaire. The understanding of integrity was measured according to the Hadith of the Prophet by Hanafi Hamdani (2014), professional values aspect was measured using Wilson (2010) survey questionnaire on moral reasoning and ethical decision making and academic ethics practices were measured using the College Teaching Behaviors Inventory (CTBI) developed by Braxton \& Bayer (2003). Stratified sampling technique was used as the sampling method where 439 lecturers were randomly selected from five Islamic Higher Education institutions in Aceh, Indonesia. Data were analyzed based on multiple regressions. The findings showed that there was no significant effect of understanding of integrity $[\mathrm{p} \geq .05(.085)]$ and professional values $[\mathrm{p} \geq .05(.140)]$ on lecturers' academic ethics practices. However, the findings of this study also showed that a greater understanding of integrity contributed to the change in academic ethics of Islamic Higher Education lecturers. The implication of this study is that the aspect of understanding of integrity and professional values can be enhanced through courses and training organized by the top management of Islamic Higher Education institutions. These aspects should be emphasized among the lecturers so that they can serve as role models for the younger generation.
\end{abstract}

Keywords Understanding Integrity, Professional Values, Academic Ethical Practices

\section{Introduction}

Academic ethics is a guide in terms of responsibilities, roles and behaviors for a college lecturer. Thus, academic ethics is best used as a guide in action and decision-making when facing ethical dilemmas. According to the National Institute of Public Administration or INTAN (1991), ethics is a set of references to behaviors and procedures to be followed or any moral principles to be adhered to or a set of behaviors that each member of the organization should follow and observe.

However, there are a number of study findings which found various lecturers' misconduct including unfairness in assessment, frequent acts of favoritism, tardiness, failure to perform administrative tasks, using inappropriate words during teaching and research sessions. Without proper action, the ethics and integrity of educators or lecturers will diminish slowly (De Russy, 2003).

Lecturers have also been reported to commit ethical violations in educational institutions such as establishing intimate relationships with students, disrupting coursework, and disobeying university regulations. In addition, there was also a case of a university lecturer in Aceh being charged for corruption in 2007. For instance, there were three lecturers, including the rector at one of the public universities in Aceh, Indonesia committed corruption by using students' funds for personal gains in 2010. They were all sentenced by the civil courts in Aceh, Indonesia.

Therefore, this study was conducted to examine the influence of understanding integrity and professional values on academic ethics practice among lecturers. Through this study, the researcher was able to look at the issues and problems that arose in relation to the variables involved and discuss in more detail the solution to addressing the problem. From this, the study is hoped to help lecturers not to focus on negative things for the development and future of the nation. 


\section{Research Objectives}

The objectives of this study were to:

1. Identify the level of understanding integrity and professional values on the academic ethics practices of lecturers.

2. Identify significant differences in the academic ethics practices of lecturers based on age and gender.

3. Identify the significant impact of understanding integrity and professional values on the academic ethics practices of lecturers.

\section{Research Questions}

The research questions were as follows:

1. What is the lecturers' level of understanding integrity and professional values on the academic ethics practices?

2. Are there significant differences in the academic ethics practices of lecturers based on age and gender?

3. Is there any significant impact of understanding integrity and professional values on lecturers' academic ethics practices?

\section{Research Methodology}

This quantitative study used descriptive survey method based on the questionnaire that the respondents answered. Quantitative research method was used because this study involved the process of collecting respondents' data using a questionnaire from a large number of respondents (Cohen, 2000). Among the advantages of using this method are that it allows more data to be collected at a time, more cost-effective and convenient use of the process (Creswell, 1997; Hofstede, Neuijen, Ohayv and Sanders, 1990). In addition, the use of the questionnaire instrument in this study also made the study more focused and in depth and was able to achieve the well defined objectives of the study (Sachman, 1991).

The researcher used a stratified sampling method to determine the selected sample. The stratified sampling method is a sampling technique in which the study population is grouped into specific strata. This method was used to determine the sample consisting of lecturers in the State Islamic University (UIN), State Islamic Religious Institutions (IAIN) and State Islamic Religious High Schools (STAIN). There were a total of 1115 lecturers in Islamic Higher Education in Aceh, Indonesia. Based on the population, the researcher has selected 439 lecturers as the study sample.

The questionnaire instrument used to measure understanding of integrity consisted of 36 items with a reliability value of $\alpha=.87$ and the questionnaire for professional values consisted of 9 items with a reliability value of $\alpha=.73$. Meanwhile, the questionnaire to measure the academic ethics of lecturers consisted of 126 items with a reliability value of $\alpha=.92$.

\section{Finding}

\subsection{Lecturers' Level of Understanding Integrity and Professional Values in the Academic Ethics Practices}

An analysis of lecturers' level of understanding integrity and professional values in the academic ethics practices was based on mean values as well as the standard deviation from the responses of 439 respondents among the lecturers at Islamic Higher Education. The total mean score obtained reflected the level of lecturers' academic ethics practices. High level referred to mean scores of 3.67 to 5.00 , medium level referred to mean scores of 2.34 to 3.66 and low level referred to mean scores of 1.00 to 2.33. Therefore, based on the analysis, the level of aspects of understanding integrity $(\mathrm{M}=4.27, \mathrm{SD}=.38)$ and professional values $(\mathrm{M}=3.90$, $\mathrm{SD}=.41)$ was high.

\subsection{Differences in Lecturers' Academic Ethics Practices by Age}

One-way analysis of variance (ANOVA) was used to identify significant differences in academic ethics practices among lecturers based on age. The results of the analysis showed that there was no significant difference in academic ethics practices among lecturers based on age, $\mathrm{F}$ $(42,396)=.906, \mathrm{p}>.05(.642)$. This finding indicated that there was no significant difference in academic ethics practices among lecturers based on the age. Therefore, the findings accepted the null hypothesis that there is no difference in academic ethics practices among lecturers based on age.

Table 1. ANOVA result of Lecturers' Academic Ethics Practices by Age

\begin{tabular}{|c|c|c|c|c|c|}
\hline Source & SS & $D f$ & $M S$ & $F$ & Sig. \\
\hline Between Groups & 12.713 & 42 & .303 & .906 & .642 \\
\hline In Group & 132.354 & 396 & .334 & & \\
\hline Totals & 145.067 & 438 & & & \\
\hline
\end{tabular}

$* p<0.05$

\subsection{Differences in Lecturers' Academic Ethics Practices by Gender}

Independent sample T-test analysis was used to identify significant differences in academic ethics practices among lecturers based on gender. The results of the analysis showed that the mean score and standard deviation for males were $(\mathrm{M}=3.49, \mathrm{SD}=.57)$ and females were $(\mathrm{M}=$ $3.45, \mathrm{SD}=.58)$. T-test results found that the $\mathrm{t}$ value was .54 , at a significant level of $.59(\mathrm{p}>.05)$. This indicated that 
there was no significant difference in lecturers' academic ethics practices based on gender. Therefore, this study has accepted the null hypothesis that there is no significant difference in academic ethics practices among lecturers based on gender.

Table 2. T-Test Result Lecturers' Academic Ethics Practices by Gender

\begin{tabular}{|c|c|c|c|c|c|c|}
\hline Gender & $N$ & Mean & $S D$ & $D f$ & $t$ & $P$ \\
\hline Male & 283 & 3.49 & .57 & 437 & .54 & .59 \\
\hline Female & 156 & 3.45 & .58 & & & \\
\hline
\end{tabular}

$* \mathrm{p}<0.05$

\subsection{Impact of Understanding Integrity and Professional Values on Lecturers' Academic Ethics Practices}

Regression model analysis revealed that there were two predictor variables for academic ethics practices - namely, an understanding of integrity and professional values that were included in the regression model at $\leq .05$. The correlation between dependent variable and predictor variable of understanding integrity was .113. Subsequently, the correlation between dependent variable and predictor variable of professional values was .105.

The $\mathrm{R}^{2}$ value of .013 indicated that 1.3 per cent of change in the dependent variable (academic ethics practices) was due to the change in understanding integrity. The combination of understanding integrity and professional values contributed (1.8-1.3) percent, which was 0.5 percent of the additional change in academic ethics practices. The linear combination of the two predictor variables accounted for 1.8 percent of the variance in the dependent variable. This can be seen in Table 3 .

The results of the data analysis indicated that for the study population $($ sample size $=439$ ), two predictor variables namely understanding integrity (a) and professional values (b) were predictors of lecturers' academic ethics practices. This suggested that the results of the study accepted the assumption that understanding integrity and professional values variables was a predictor of lecturers' academic ethics practices at Islamic Higher Education in Aceh.

Significantly, the understanding integrity score $[\mathrm{F}$ (1, $437)=5.690, p<.05]$ accounted for 1.3 percent of the variance $\left(\mathrm{R}^{2}=.013\right)$ in lecturers' academic ethics practices. This meant that understanding integrity $(\beta=.168, \mathrm{p}<.05)$ was a key indicator as to the reason lecturers at Islamic Higher Education were practicing academic ethics. The combination of understanding integrity $(\beta=.129, p>.05)$ and professional values $(\beta=.103, \mathrm{p}>.05)$ increased by $(1.8-1.3)$ percent or 0.5 percent to the variance $\left(\mathrm{R}^{2}=.018\right)$ in academic ethics practices $[\mathrm{F}(2,436)=3.946, \mathrm{p}<.05]$. This situation indicated that predictor variable understanding integrity contributed more to changes in academic ethics practices compared to professional values predictor variable.

Table 3 shows the regression model analysis in which the two predictors of the dependent variable (academic ethics practices), namely understanding integrity $[p \geq .05$ (.085)] and professional values $[p \geq .05(.140)]$ showed non-significant value. This indicated that both predictor variables have no effect on the lecturers' academic ethics practices. Therefore, the null hypothesis that there is no significant influence of understanding integrity and professional values on academic ethics practices among lecturers was accepted. Concisely, the findings showed that the two variables were not significant and did not give any impact on the academic ethics practices of Islamic Higher Education lecturers in Aceh. Overall, the variable understanding integrity has shown to give more contribution and influence to the change in the academic ethics practices among Islamic Higher Education lecturers in Aceh, Indonesia compared to the professional values variable. Meanwhile, professional values variable was not significant and has given less contribution to the change in academic ethics practices of Islamic Higher Education lecturers.

Table 3. Multiple Regression Analysis of Understanding Integrity and Professional Values in Lecturers' Academic Ethics Practices

\begin{tabular}{|c|c|c|c|c|c|c|c|c|c|}
\hline & Model & $\mathbf{R}$ & $\mathbf{R}^{2}$ & $\mathbf{F}$ & $\beta$ & SE B & Beta & t & Sig. \\
\hline \multirow[t]{2}{*}{1} & Constant & $.113^{\mathrm{a}}$ & .013 & 5.690 & 2.763 & 302 & & 9.155 & .000 \\
\hline & $\begin{array}{l}\text { Understanding } \\
\text { Integity }\end{array}$ & & & & .168 & .070 & .113 & 2.385 & .017 \\
\hline \multirow[t]{3}{*}{2} & Constant & $.133^{b}$ & .018 & 3.946 & 2.523 & 342 & & 7.373 & .000 \\
\hline & $\begin{array}{l}\text { Understanding } \\
\text { Integrity }\end{array}$ & & & & .129 & .075 & .087 & 1.728 & .085 \\
\hline & Professional Values & & & & .103 & .070 & .075 & 1.479 & .140 \\
\hline
\end{tabular}

a. Understanding Integrity

b. Understanding Integrity \& Professional Values

The dependent variable: Academic Ethics Practices 


\section{Discussions, Implications and Suggestions}

\subsection{Understanding Integrity Level}

The level of understanding integrity among the respondents in this study was high. This finding is in line with a study conducted by Hanafi Hamdani (2014) in which he found that the level of understanding integrity among the administrative staff of UiTM Shah Alam, Selangor was high. Similarly, a study conducted by Zalinah Mohamed (2014) found that the level of understanding integrity among primary school teachers in four schools around Tampoi, Johor Bahru, with regards to the implementation of School-Based Assessment based on the Primary School Curriculum Standards (KSSR), was high.

\subsection{Professional Values Level}

The level of professional values among the respondents in this study was also high. This finding is in line with studies conducted by Mohamad Nizam Nazarudin, Nur Fatihah Luciana Benjamin Abdullah and Zakiah Noordin (2017) who found that the level of professional values of trainee teachers during the practicum at the Sabah Zone Teacher Education Institute was high. However, the finding of this study is also not in line with the study conducted by Noor Rosmawati Yusuf, Abdul Razak Ahmad and Mohd Mahzan Awang (2017) who found that the level of professional values of Malaysian Polytechnic lecturers was at a relatively high level.

The finding of the study conducted by Nur Hafizoh and Rohana (2013) was contrary to the findings of this study where they found that the practice of teaching professionalism based on the Malaysian Teacher Standards among the Malaysian University of Technology teachers showed that it was at a moderate level. This has been proven by analysis that showed that the level of interpersonal and intrapersonal skills was the highest practices followed by belief in God as well as leadership practices. Therefore, the overall research finding on the level of professionalism practice was only at a moderate level.

\subsection{Differences in Lecturers' Academic Ethics Practices by Age}

The finding of this study showed that there was no significant difference in academic ethics practices among lecturers based on age $(\mathrm{p}=.642)$. This finding is in line with a study conducted by Ainuddin Mohd Isa (2017) who found that there was no significant difference in academic ethics practices among teachers of the Teacher Education Institute by age. This indicated that the age category did not impact the academic ethics practices among the Islamic Higher Education lecturers. In other words, the level of academic ethics practices among lecturers was the same despite differences in age.

The finding of this study is also in line with the study conducted by Syaifulradzman Shaifuddin (2012) who found that there was no significant difference between age categories compared to an individual's academic ethics practices. This indicated that the older age category who have more experience and has a longer service period is the same as the practice of academic ethics among the younger age groups.

Therefore, researchers remain consistent with the result of this study that there is no significant difference in academic ethics practices based on one's age. Although the theory has stated otherwise, these differences may have been influenced by other aspects that may be beyond this study. Vast difference in ages certainly would make a significant difference based on the courses and seminars they have attended and the experience gained during their service. However, reality has shown that there is no significant difference in one's academic ethics practices by age category.

\subsection{Differences in the Lecturers' Academic Ethics Practices by Gender}

The finding of this study showed that there was no significant difference in academic ethics practices among lecturers based on gender $(\mathrm{p}=.589)$. This finding is in line with the study by Ainuddin Mohd Isa (2017) who found no significant difference between a person's gender and the academic ethics practices among Teacher Education Institute lecturers. The study finding by Ainuddin Mohd Isa (2017) showed that there was no significant difference in academic ethics practices of male lecturers compared to female lecturers. Thus, this proved that the practice of academic ethics practices among male and female lecturers was the same despite differences in gender.

However, this finding is contrary to a study conducted by Shazaitul Azreen Rodzalan and Maisarah Mohamed Saat (2016), which focused more on undergraduate students as respondents in their study, where there was a significant difference in academic ethics practices among students based on gender. The study found that female students have higher levels of academic ethics practices than male students.

Therefore, it can be concluded that each study has different findings. However, academic ethics practices should not be different in terms of gender as individuals need to maintain a high level of ethics practices within themselves and these academic ethics practices should be enhanced constantly in order to achieve excellence in themselves and for their nation.

\subsection{Impact of Understanding Integrity and Professional Values on Lecturers' Academic Ethics Practices}

The finding of this study found that there was no 
significant effect of understanding integrity and professional values on academic ethics practices among lecturers. According to Rashidi Abbas, Fakhrul Adabi Abdul Kadir and Ilhamie Abdul Ghani Azmi (2014), aspects of understanding integrity and professional values such as persistence and sincerity in the individual, despite their status, should always be implemented and enhanced. It is believed that these aspects influence the development of ethical values in oneself. At the same time, the development of quality students and workers in all aspects of Islamic values is considered the utmost importance and is given bigger attention towards improving the nation.

In addition, a lecturer or leader should also be an example and display a good attitude and trust in his students as such is one of the characteristics of an ethical lecturer. The practice of academic ethics not only disciplines students but also benefits those around them. Therefore, the researchers do not agree with the findings of this study but strongly propose that aspects of understanding integrity as well as professional values certainly influence the practice of academic ethics in individuals. In fact, the researchers believe that both of these factors are the driving force and catalyst for academic ethics practices.

\section{Implications of the Study}

Cases of misconduct or ethical violations among lecturers as presented by the researchers in this study are indeed commonplace and occur in any educational institution in any country. Thus, the inculcation and ingestion of more ethical leadership values among lecturers is a jihad to ensure that repeated incidents of misconduct do not occur. In addition, the Ministry of Education is expected to take various actions to inculcate ethical values in each lecturer and student. This endeavor is seen as the best, right and pure way. All types of programs, courses, briefings and seminars need to be organized following these aspects so that these positive elements will always be updated in their daily lives.

Based on the findings of this study, the researchers also suggested that the university should conduct courses or training on academic ethics practices among the lecturers from time to time. Through these courses and training, further academic ethics practices can be enhanced in each of the lecturers while learning more positive values in academic ethics, especially regarding university teaching and learning. At the same time, these courses and exercises can also help to make more ethical decisions among lecturers.

Furthermore, the university should also recommend that lecturers with lower academic qualifications attend training on academic ethics practices from time to time. It aims to minimize the difference in terms of academic ethics practices that exists among lecturers. At the same time, lecturers with high academic qualifications such as a Doctorate of Philosophy should also ensure that their academic ethics practices are maintained and strengthened. This way, the practice of academic ethics among lecturers will not display any gaps or differences despite having different academic qualifications.

\section{Suggestions for Advanced Study}

The findings of this study have contributed in examining the differences of academic ethnics practices based on the demographic aspects of the respondents' age and gender. Therefore, for further study future researchers may extend the demographic aspects of the respondents such as religion, social environment, socio economic level, cultural dimension and so on. As such, different findings, a more comprehensive and detailed contribution will be contributed to the readers. At the same time, the findings of this study can serve as the basis for studies related to academic ethics practices among lecturers.

Furthermore, future studies may also extend this study by using qualitative methods or by combining both methods quantitatively and qualitatively. According to Scott and Garner (2013), the use of 'mixed method' has the advantage of providing a clearer qualitative study and contextualization through quantitative studies. In addition, researchers using qualitative methods will find more accurate, comprehensive, reliable, quality and meaningful research findings. At the same time, it will emphasize on inductive reasoning to understand a particular situation or circumstances, including the history or experience of an individual. The study based on in-depth interviews, observations and document analysis can be carried out by the researcher to further strengthen the findings. Therefore, this proposal is best applied by the next researcher.

Further research is also expected to reach a larger number of respondents as well as more cities in Indonesia. As this study only involved Islamic Higher Education available in the city of Aceh, the researchers suggest that future studies can be expanded throughout the cities in Indonesia by involving lecturers from every age group. Comparative studies of urban and rural universities on this topic are also encouraged.

\section{Conclusions}

Overall, the research conducted have opened up opportunities as well as become a starting point for other researchers to make or continue their research in related fields that have not been fully explored. Of course, future studies can refine the same field from different points of view. However, the most important thing in a study is that each view or study is able to contribute as well as a reference material to achieve something better. 


\section{Acknowledgements}

The authors wished to thank University Utara Malaysia for funding this study under the Postgraduate Research Grant, and the Research and Innovation Management Centre (RIMC), University Utara Malaysia for the administration of this study.

\section{REFERENCES}

[1] Ainuddin Mohd Isa. (2017). Penaakulan moral, nilai profesional dan membuat keputusan terhadap amalan etika akademik dalam kalangan pensyarah Institut Pendidikan Guru. Tesis Doktor Falsafah. Sintok: Universiti Utara Malaysia.

[2] Braxton, J. M., \& Bayer, A. E. (2003). Faculty misconduct in collegiate teaching. Baltimore, MD, USA: The John Hopkins University Press.

[3] Cohen, L. (2000). Research methods in education (5th ed). London: Routledge Falmer.

[4] Creswell, J. W. (1997). Qualitative inguiry and research designs: Choosing among five traditions. Thousand Oaks, CA: Sage.

[5] De Russy, C. (2003). Professional ethics begin on the colleges campus. The Chronicle of Higher Education, September, 19, B20.

[6] Hanafi Hamdani. (2014). Integriti menurut Hadith Nabi: Kajian terhadap kefahaman kakitangan pentadbiran UiTM Shah Alam. Tesis Ijazah Sarjana. Universiti Malaya.

[7] Hofstede, G., Neuijen, B., Ohayv, D. D., \& Sanders, G. (1990). Measuring organizational cultures: A qualitative and quantitative study across twenty cases. Administrative Science Quarterly, 35(2), 286-316.

[8] Institut Tadbiran Awam Negara. (1991). Nilai dan etika dalam perkhidmatan awam. Kuala Lumpur: INTAN.

[9] Mohamad Nizam Nazarudin, Nur Fatihah Luciana Benjamin Abdullah \& Zakiah Noordin. (2017). Profesionalisme, kesediaan mengajar guru pelatih dan penyeliaan pengajaran pensyarah pembimbing praktikum di Institut Pendidikan Guru Zon Sabah. International Journal of Education, Psychology and Counseling, 2(4), 71-84.

[10] Noor Rosmawati Yusuf, Abdul Razak Ahmad \& Mohd Mahzan Awang. (2017). Amalan profesional ke arah mengukuhkan profesionalisme dalam kalangan pensyarah Politeknik Malaysia. Fakulti Pendidikan, Universiti Kebangsaan Malaysia, 999-1007.

[11] Nur Hafizoh Idris \& Rohana Hamzah. (2013). Nilai profesionalisme bakal guru berteraskan indikator Standard Guru Malaysia (SGM). Jurnal Teknologi, 60, 31-37.

[12] Rashidi Abbas, Fakhrul Adabi Abdul Kadir \& Ilhamie Abdul Ghani Azmi. (2014). Kemahiran generik: Hubungan nilai amanah dengan etika dan moral profesional dalam kalangan pelajar Universiti Teknikal Malaysia (MTUN Universiti). Online Journal of Islamic Education, 2(2), 1-15.
[13] Sachman, H. (1991). Delphi critique. Lexington, MA: Lexington Books.

[14] Scott, G., \& Garner, R. (2013). Doing qualitative research: Designs, methods and techniques. Upper Saddle River, NJ: Pearson.

[15] Shazaitul Azreen Rodzalan \& Maisarah Mohamed Saat. (2016). Ethics of undergraduate students: A study in Malaysian public universities. International Journal of Information and Education Technology, 6(9), 672-678.

[16] Syaifulradzman Shaifuddin. (2012). Kajian tahap amalan kerja beretika pemeriksa audit dalam di Politeknik Malaysia (Kawasan Utara). Tesis Ijazah Sarjana. Sintok: Universiti Utara Malaysia.

[17] Wilson, V. B. (2010). Examining moral reasoning and ethical decision making among Mississippi's community college administrators. ProQuest LLC 789 East Eisenhower Parkway P.O. Box 1346 Ann Arbor.

[18] Zalinah Mohamed. (2014). Integriti guru dalam pelaksanaan Pentaksiran Berasaskan Sekolah Kurikulum Standard Sekolah Rendah di empat buah sekolah rendah di daerah Tampoi, Johor Bahru. Ijazah Sarjana Pendidikan. Fakulti Pendidikan: Universiti Teknologi Malaysia. 